\title{
PENGARUH PEMBELAJARAN BERBASIS PROYEK DIPADU DENGAN METODE PEMECAHAN MASALAH PADA KETERAMPILAN BERPIKIR KREATIF SISWA
}

\author{
Berliana Putri Santoso ${ }^{1}$., Fitria Eka Wulandari ${ }^{2}$ \\ ${ }^{1}$ Prodi Pendidikan IPA FPIP Universitas Muhammadiyah Sidoarjo, Indonesia \\ e-mail: berlinaputrisantoso023@umsida.ac.id \\ ${ }^{2}$ Prodi Pendidikan IPA FPIP Universitas Muhammadiyah Sidoarjo, Indonesia \\ e-mail: fitriaekawulandari@umsida.ac.id
}

\begin{abstract}
Submit: 08-06-2020 Revisi: 08-07-2020 Diterima: 10-07-2020 Diterbitkan: 17-08-2020
Abstrak: Keterampilan berpikir kreatif menjadi capaian utama lulusan pendidikan di era industri 4.0, namun keterampilan tersebut masih kurang dilatihkan di sekolah. Oleh karena itu, tujuan penelitian ini adalah untuk mengetahui pengaruh pembelajaran berbasis proyek dipadu metode pemecahan masalah terhadap keterampilan berpikir kreatif siswa dalam pembelajaran IPA SMP. Jenis penelitian ini adalah kuasi eksperimen dengan pre-test \& post-test kontrol group design. Populasi penelitian adalah siswa kelas IX SMP Muhammadiyah 6 Krian. Sampel diambil dengan teknik purposive sampling sehingga diperoleh 54 siswa di kelas IX-C dan IX-D. Instrumen yang digunakaan adalah tes berpikir kreatif dengan indikator kelancaran, fleksibilitas, orisinilitas, dan elaborasi. Analisis data yang digunakan adalah uji independent simple t-test dengan menggunakan aplikasi SPSS. Hasil penelitian menunjukkan adanya peningkatan setiap indikator berpikir kritis pada sebelum dan setelah diterapkan pembelajaran berbasis proyek dipadu metode pemecahan masalah. Nilai post-test keterampilan berpikir kreatif pada kelas eksperimen lebih tinggi dibandingkan kelas kontrol. Selain itu, hasil uji-t diperoleh nilai signifikansi $<0,05$. Dengan demikian, pembelajaran berbasis proyek dipadu dengan metode pemecahan masalah berpengaruh signifikan pada keterampilan berpikir kreatif siswa dalam pembelajaran IPA.
\end{abstract}

Kata kunci: Berpikir Kreatif, Pembelajaran Berbasis Proyek, Pemecahan Masalah

\section{THE EFFECTS OF PROJECT-BASED LEARNING COMBINED WITH PROBLEM SOLVING METHODS ON STUDENTS' CREATIVE THINKING SKILL}

\begin{abstract}
The creative thinking skill becomes a major achievement of education graduates in the industrial era 4.0, but it is still lacking in-school training. Therefore, the purpose of this study was to determine the effect of project-based learning combined with problem-solving methods on students' creative thinking skills in learning the science of junior high school. This type of research is a quasiexperimental with pretest \& posttest kontrol group design. The study population was grade IX students of Muhammadiyah 6 Krian Middle School. Samples were taken with a purposive sampling technique to obtain 54 students in class $I X C$ and $I X D$. The instrument used was a test of creative thinking with indikators of fluency, flexibility, originality, and elaboration. Analysis of the data used is the independent simple t-test using the SPSS application. The results showed an increase in each indikator of critical thinking before and after project-based learning was applied combined with problem-solving methods. The post-test score of the ability to think creatively in the experimental class was higher than the control class. Also, the t-test results obtained a significant value is 0.00 $<0.05$. Thus, project-based learning combined with problem-solving methods significantly influences students' creative thinking skills in learning science.
\end{abstract}

Keywords: Creative Thinking, Problem-Solving, Project-Based Learning 
Santoso \& Wulandari. (2020). Pengaruh Pembelajaran Berbasis Proyek Dipadu dengan Metode Pemecahan Masalah pada Keterampilan Berpikir Kreatif Siswa

\section{PENDAHULUAN}

Pendidikan merupakan salah satu hal yang penting untuk mencetak siswa yang aktif dan kreatif dalam mengembangkan kemampuan yang dimilikinya sehingga mereka memiliki kecerdasan intelektual, emosional, maupun spiritual. Pendidikan juga berusaha membentuk akhlak mulia serta menumbuh kembangkan keterampilan-keterampilan yang diperlukan, baik untuk dirinya sendiri, masyarakat ataupun lingkungan disekitarnya (Mulhayatiah, 2014; Fahmi \& Irhasyuarna, 2019). Selain itu, salah satu tujuan pendidikan adalah mampu menjadikan siswa berpikir kreatif dalam hal memecahkan atau menyelesaikan masalah yang dihadapi maupun keterampilan menyampaikan pemikirannya (Armandita dkk., 2017). Keterampilan berpikir kreatif ini menjadi salah satu faktor kunci untuk mengatasi berbagai permasalahan yang kompleks di era industri 4.0 (Rif'at dkk., 2020; Zainuddin dkk., 2020; Yanti dkk., 2020). Melalui pengembangan keterampilan berpikir kreatif ini, siswa dipersiapkan dalam penemuan keilmuan, inovasi teknologi, dan pengambilan keputusan dalam memecahkan masalah kehidupan nyata (Suyidno dkk., 2017; 2018; Zainuddin dkk., 2020).

Keterampilan berpikir kreatif siswa hingga saat ini belum mendapatkan perhatian lebih dalam proses pembelajaran IPA. Masalah yang sering dijumpai di sekolah adalah pembelajaran yang tidak sesuai dengan tuntutan kurikulum. Proses pembelajaran IPA yang cenderung monoton menyebabkan hasil belajar siswa tidak lagi berpengaruh signifikan terhadap keterampilan berpikirnya (Fuadah dkk., 2019; Suyidno dkk., 2020). Rendahnya keterampilan berpikir kreatif mengakibatkan siswa kesulitan dalam memecahkan masalah yang sedang maupun yang akan dihadapi dalam proses pembelajaran (Amtiningsih dkk., 2016; Rif'at dkk., 2020). Hal ini diperkuat hasil observasi awal peneliti pada 20 siswa SMP Muhammadiyah 6 Krian yang diambil secara acak dan diperoleh informasi bahwa 17 dari 20 siswa tidak kreatif dengan tingkat kreativitas 7\%-15\%, 3 dari 20 siswa cukup kreatif dengan tingkat kreativitas antara 23\%-30\%. Hasil ini mengindikasikan bahwa tingkat kreativitas siswa masih rendah. Hal ini belum sesuai dengan amanah Undang-undang Sistem Pendidikan Nasional No. 20 tahun 2003 Pasal 4 bahwa pendidikan berfungsi mengembangkan keterampilan dan membentuk pola pikir serta mencerdaskan kehidupan bangsa; bertujuan untuk berkembangnya potensi siswa menjadi manusia yang beriman, bertaqwa kepada Tuhan Yang Maha Esa, berakhlak mulia, berilmu, mandiri, berpikir kreatif serta bertanggung jawab. Oleh karena itu, pengembangan keterampilan berpikir kreatif menjadi salah satu permasalahan utama dalam dunia pendidikan yang perlu segera diselesaikan.

Permasalahan keterampilan berpikir kreatif siswa perlu diatasi melalui inovasi pembelajaran, di mana inovasi tersebut mampu merangsang keterampilan berpikir kreatif siswa salah satunya dengan menggunakan pembelajaran berbasis proyek. Pembelajaran berbasis proyek merupakan suatu model pembelajaran yang menggunakan proyek sebagai media, siswa dapat melakukan eksplorasi, penilaian, interpretasi, sintesis, dan mengumpulkan informasi untuk menghasilkan berbagai bentuk hasil belajar (Wulandari, 2016). Guru dapat mengelola pembelajaran di kelas dengan melibatkan kerja proyek untuk meningkatkan kreativitas siswa (Masinta \& Astutik, 2016). Model ini berpengaruh secara signifikan terhadap keterampilan berpikir kreatif dan hasil belajar siswa (Mulhayatiah, 2014). Untuk mengoptimalkan pembelajaran berbasis proyek, perlu dipadu dengan metode pembelajaran yang sesuai. Metode pembelajaran yang diyakini sesuai di antaranya adalah metode pemecahan masalah. Metode pemecahan masalah termasuk salah satu strategi pembelajaran yang menggunakan penyelesaian masalah bersifat umum yang dapat mendorong siswa berpikir kreatif. Dari penyelesaian masalah umum tersebut diharapkan siswa mampu menemukan jawaban yang bervariasi atas dasar kreativitas dan keterampilan yang dimilikinya. Hal ini didukung hasil penelitian Triyono dkk. (2019) bahwa penerapan pemecahan masalah kreatif dalam pembelajaran IPA berpengaruh positif terhadap kreativitas siswa. Siswa merasakan pengalaman langsung dalam mengaktualisasi ide-ide kreatifnya dalam mendesain produk kreatif yang berguna untuk menyelesaikan masalah (Yanti dkk., 2020).

Berdasarkan uraian di atas, penelitian ini bertujuan untuk mengetahui pengaruh pembelajaran berbasis proyek dipadu dengan metode pemecahan masalah terhadap keterampilan berpikir kreatif siswa dalam pembelajaran IPA SMP. Penelitian ini diharapkan mampu memberikan hasil yang sesuai, di mana dalam metode pemecahan masalah siswa dihadapkan pada masalah bersifat umum, sehingga mereka diharapkan mampu menyusun pengetahuannya sendiri dan mengupayakan berbagai macam solusi untuk menyelesaikannya. Siswa dimungkinkan lebih aktif dan kreatif dalam proses mencari dan menemukan hasil belajar IPA yang dipelajarinya. 


\section{METODE PENELITIAN}

Penelitian ini menggunakan metode kuasi eksperimen dengan Nonequivalent Kontrol Group Design. Populasi penelitian adalah siswa kelas IX SMP Muhammadiyah 6 Krian. Pengambilan sampel menggunakan teknik purposive sampling, yaitu teknik penentuan suatu sampel dengan pertimbangan tertentu (Sugiyono, 2012). Berdasarkan teknik tersebut, sampel yang terpilih adalah dari 2 kelas, yaitu 27 siswa kelas IX-C sebagai kelas eksperimen dan 27 siswa kelas IX-D sebagai kelas kontrol. Adapun desain penelitian yang digunakan adalah pre-test and post-test kontrol group design seperti disajikan pada Gambar 1.

Keterangan:

\begin{tabular}{|llll|}
\hline $\mathrm{O}_{1}$ & $\mathrm{X}$ & $\mathrm{O}_{2}$ & Eksperimen \\
$\mathrm{O}_{3}$ & & $\mathrm{O}_{4}$ & Kontrol \\
\hline
\end{tabular}

$\mathrm{O}_{1}=$ Nilai pre-test kelas eksperimen

$\mathrm{O}_{2}=$ Nilai post-test kelas eksperimen

$\mathrm{O}_{3}=$ Nilai pre-test kelas kontrol

$\mathrm{O}_{4}=$ Nilai post-test kelas kontrol

$\mathrm{X}=$ Perlakuan dengan model pembelajaran berbasis proyek dipadu metode pemecahan masalah

Teknik pengumpulan data menggunakan pre-test dan post-test berpikir kreatif yang didesain untuk mengukur indikator berpikir kreatif, yaitu kelancaran, fleksibilitas, orisinilitas, dan elaborasi. Selanjutnya, data yang telah diperoleh diuji menggunakan independent simple t-test berbantuan SPSS. Dalam analisis ini, siswa dapat dikelompokkan berdasarkan tingkat berpikir kreatifnya dalam lima kelompok, yaitu: sangat kreatif, kreatif, cukup kreatif, kurang kreatif, dan tidak kreatif. Interval interpretasi skor berpikir kreatif disajikan pada Tabel 1.

\begin{tabular}{cc} 
Tabel 1. Kriteria interpretasi & skor berpikir kreatif \\
\hline Interval Skor (\%) & Tingkat KBK \\
\hline $0<\mathrm{x} \leq 20$ & Tidak kreatif \\
$20<\mathrm{x} \leq 40$ & Kurang kreatif \\
$40<\mathrm{x} \leq 60$ & Cukup Kreatif \\
$60<\mathrm{x} \leq 80$ & Kreatif \\
$80<\mathrm{x} \leq 100$ & Sangat kreatif \\
\hline
\end{tabular}

\section{HASIL DAN PEMBAHASAN}

Data keterampilan berpikir kreatif siswa diperoleh dari hasil pre-test dan post-test. Adapun hasil nilai pre-test dan post-test kelas eksperimen maupun kelas kontrol dapat dilihat pada Tabel 2 dan Tabel 3.

Tabel 2. Hasil pre-test dan post-test eksperimen

\begin{tabular}{cccccc}
\hline \multirow{2}{*}{ No } & \multicolumn{2}{c}{ Kelas Eksperimen } & \multirow{2}{*}{ No } & \multicolumn{2}{c}{ Kelas Eksperimen } \\
\cline { 2 - 3 } & Nilai Pre-test & Nilai Post-test & & Nilai Pre-test & Nilai Post-test \\
\hline 1 & 6 & 47 & 15 & 16 & 55 \\
2 & 15 & 44 & 16 & 21 & 53 \\
3 & 18 & 44 & 17 & 9 & 57 \\
4 & 14 & 53 & 18 & 19 & 54 \\
5 & 12 & 50 & 19 & 15 & 33 \\
6 & 10 & 53 & 20 & 9 & 33 \\
7 & 14 & 54 & 21 & 21 & 46 \\
8 & 16 & 54 & 22 & 6 & 37 \\
9 & 15 & 51 & 23 & 13 & 33 \\
10 & 6 & 47 & 24 & 12 & 44 \\
11 & 18 & 45 & 25 & 13 & 60 \\
12 & 0 & 44 & 26 & 10 & \\
13 & 19 & 42 & 27 & 19 & \\
14 & 21 & 53 & & & \\
\hline
\end{tabular}


Santoso \& Wulandari. (2020). Pengaruh Pembelajaran Berbasis Proyek Dipadu dengan Metode Pemecahan Masalah pada Keterampilan Berpikir Kreatif Siswa

Tabel 3. Hasil pre-test dan post-test kelas kontrol

\begin{tabular}{cccccc}
\hline \multirow{2}{*}{ No } & \multicolumn{2}{c}{ Kelas Eksperimen } & \multirow{2}{*}{ No } & \multicolumn{2}{c}{ Kelas Eksperimen } \\
\cline { 2 - 3 } & Nilai Pre-test & Nilai Post-test & & Nilai Pre-test & Nilai Post-test \\
\hline 1 & 13 & 26 & 15 & 16 & 21 \\
2 & 13 & 24 & 16 & 25 & 19 \\
3 & 19 & 20 & 17 & 18 & 19 \\
4 & 21 & 16 & 18 & 3 & 32 \\
5 & 6 & 19 & 19 & 26 & 6 \\
6 & 16 & 16 & 20 & 3 & 27 \\
7 & 15 & 25 & 21 & 10 & 0 \\
8 & 28 & 47 & 22 & 3 & 28 \\
9 & 20 & 22 & 23 & 23 & 32 \\
10 & 16 & 24 & 24 & 32 & 20 \\
11 & 6 & 20 & 25 & 16 & 15 \\
12 & 27 & 24 & 26 & 3 & 23 \\
13 & 12 & 13 & 27 & 0 & \\
14 & 13 & 25 & & & \\
\hline
\end{tabular}

Tabel 2 menunjukkan nilai pre-test dan post-test kelas eksperimen mengalami kenaikan. Pada pre-test nilai tertinggi yaitu 21, sedangkan hasil post-test nilai tertinggi yaitu 66. Demikian juga nilai pre-test dan post-test kelas kontrol juga mengalami kenaikan (Tabel 3). Nilai pre-test nilai tertinggi yaitu 32 dan nilai post-test tertinggi yaitu 47. Data pre-test dan post-test keterampilan berpikir kreatif di atas dapat disajikan secara ringkas pada Gambar 2.

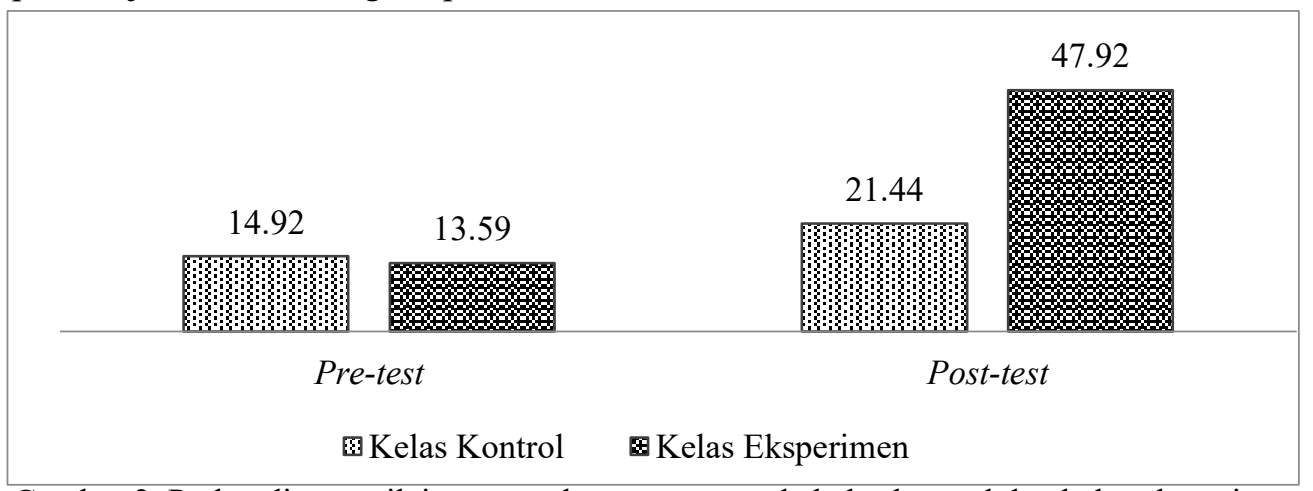

Gambar 2. Perbandingan nilai pre-test dan post-test pada kelas kontrol dan kelas eksperimen

Berdasarkan Gambar 2, hasil pre-test dan post-test pada kelas kontol mengalami kenaikan namun hanya sedikit yang mana rata-rata awalnya 14,92 menjadi 21,44 , sedangkan hasil pre-test dan post-test pada kelas eksperimen mengalami kenaikan yang cukup besar yang mana rata-rata awalnya 13,59 menjadi 47,93. Temuan di atas diperkuat dari hasil analisis perbandingan indikator keterampilan berpikir keatif pada kelas eksperimen maupun kontrol seperti disajikan pada Tabel 4.

Tabel 4. Capaian indikator berpikir kreatif pada kelas eksperimen dan kelas kontrol

\begin{tabular}{llcccc}
\hline \multirow{2}{*}{ Kelas } & \multirow{2}{*}{ Indikator } & \multicolumn{2}{c}{ Pre-test } & \multicolumn{2}{c}{ Post-test } \\
\cline { 3 - 6 } & & Skor (\%) & Kategori & Skor (\%) & Kategori \\
\hline \multirow{2}{*}{ Eksperimen } & Berpikir lancar & 15 & Tidak kreatif & 56 & Cukup kreatif \\
& Berpikir luwes & 11 & Tidak kreatif & 34 & Kurang kreatif \\
& Berpikir orisinil & 12 & Tidak kreatif & 45 & Cukup kreatif \\
& Berpikir terperinci & 14 & Tidak kreatif & 43 & Cukup kreatif \\
\hline \multirow{2}{*}{ Kontrol } & Berpikir lancar & 15 & Tidak kreatif & 22 & Kurang kreatif \\
& Berpikir luwes & 15 & Tidak kreatif & 24 & Kurang kreatif \\
& Berpikir orisinil & 11 & Tidak kreatif & 20 & Kurang kreatif \\
& Berpikir terperinci & 14 & Tidak kreatif & 22 & Kurang kreatif \\
\hline
\end{tabular}

Berdasarkan Tabel 4, perbandingan capaian indikator keterampilan berpikir kreatif pada kelas eksperimen dan kontrol disajikan secara ringkas pada Gambar 3. 


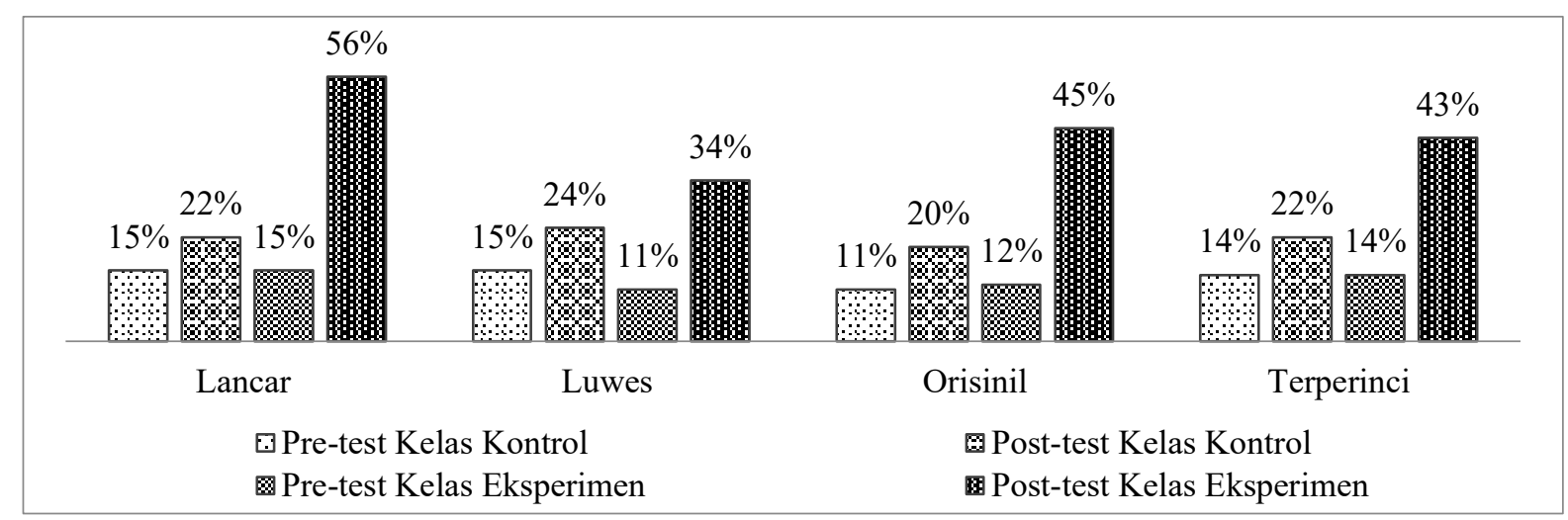

Gambar 3. Perbandingan tingkat indikator berpikir kreatif kelas kontrol dan kelas eksperimen

Berdasarkan Gambar 3, ternyata hasil pre-test menunjukkan pada awalnya keterampilan berpikir kreatif siswa pada kelas eksperimen maupun kelas kontol dalam kategori tidak kreatif. Sebaliknya, hasil post-test menunjukkan keterampilan berpikir kreatif siswa pada kelas eksperimen mengalami peningkatan, namun masih di kategori kurang/cukup kreatif. Pada kelas kontrol, setiap indikator berpikir kreatif hamper tidak mengalami kenaikan, dan masih dalam kategori kurang kreatif. Sehingga dapat disimpulkan bahwa dengan diterapkannya model pembelajaran berbasis proyek dipadu metode pemecahan masalah berpengaruh terhadap keterampilan berpikir kreatif siswa.

Selanjutnya untuk mengetahui perbedaan keterampilan berpikir kreatif antara kelas eksperimen dan kontrol dilakukan uji independent simple t-test dan didapatkan hasil nilai signifikan sebesar 0,00. Mengingat nilai sig. $<0,05$, berarti model pembelajaran berbasis proyek dipadu metode pemecahan masalah berpengaruh terhadap keterampilan berpikir kreatif siswa. Hal ini diperkuat Gambar 2 bahwa ada perbedaan rata-rata nilai post-test pada kelas eksperimen lebih tinggi dibandingkan nilai rata-rata nilai posttest pada kelas kontrol. Dari keempat indikator berpikir lancar, luwes, orisinil, dan terperinci, penerapan model pembelajaran berbasis proyek dipadu metode pemecahan masalah menunjukkan indikator berpikir lancar mendapat peningkatan tertinggi dan berpikir luwes mendapatkan peningkatan paling rendah. Kelancaran, orisinilitas, dan terperinci mampu dicapai oleh siswa dalam kategori cukup baik. Kelancaran adalah kemampuan untuk menghasilkan sejumlah besar ide atau solusi masalah, orisinilitas adalah kemampuan menghasilkan ide-ide baru dan asli, sedangkan terperinci adalah kemampuan memberikan tanggapan secara detail dan sistematis (Suyidno dkk., 2018; 2019). Dalam penelitian ini, siswa mampu menghasilkan ide-ide atau solusi masalah yang baru dan asli. Siswa juga menanggapi secara detail dan sistematis. Namun demikian, kelemahan penelitian ini adalah indikator berpikir luwes mendapat peningkatan terendah dalam kategori kurang kreatif. Keluwesan adalah kemampuan mengemukakan berbagai gagasan untuk memecahkan masalah dari berbagai sudut pandang (Suyidno dkk., 2018). Rendahnya keterampilan berpikir luwes karena dalam proses pembelajaran IPA kurang memberikan kesempatan kepada siswa untuk memberikan gagasan, sehingga gagasan yang diberikan hanya terpaku pada LKS yang diberikan oleh guru. Selain itu, perbedaan bekal pengetahuan ilmiah awal, penguasaan keterampilan proses sains, dan kurangnya kepercayaan diri siswa menjadi faktor penghambat untuk mengenali ide-ide kreatif siswa.

\section{SIMPULAN}

Implementasi model pembelajaran berbasis proyek dipadu metode pemecahan masalah berpengaruh signifikan terhadap keterampilan berpikir kreatif siswa dalam pembelajaran IPA SMP. Siswa yang pada awalnya kesulitan berpikir lancar, luwes, orisinil, dan terperinci, pada akhirnya mampu meningkatkan keterampilan tersebut meskipun masih dalam kriteria cukup/kurang kreatif. Penelitian lanjutan diperlukan untuk meningkatkan kualitas setiap indikator berpikir kreatif minimal dalam kategori baik.

\section{UCAPAN TERIMA KASIH}

Penulis mengucapkan terima kasih kepada Prodi Pendidikan Sains FPIP Universitas Muhammadiyah Sidoarjo dan SMP Muhammadiyah 6 Krian yang telah memfasilitasi penelitian ini. 
Santoso \& Wulandari. (2020). Pengaruh Pembelajaran Berbasis Proyek Dipadu dengan Metode Pemecahan Masalah pada Keterampilan Berpikir Kreatif Siswa

\section{DAFTAR PUSTAKA}

Amtiningsih, S., Dwiastuti, S., \& Sari, D. P. (2016). Peningkatan Kemampuan Berpikir Kreatif melalui Penerapan Guided Inquiry dipadu Brainstorming pada Materi Pencemaran Air. Proceeding Biology Education Conference: Biology, Science, Enviromental, and Learning, 13(1), 868-872.

Armandita, P., Wijayanto, E., Rofiatus, L., \& Susanti, N. (2017). Analisis Keterampilan Berpikir Kreatif Pembelajaran Fisika di Kelas XI Mia 3 SMA Negeri 11 Kota Jambi. Penelitian Ilmu Pendidikan, 10(2), 1-8.

Fahmi \& Irhasyuarna, Y. (2019). Pengantar Pendidikan: Manusia, Pendidikan, dan Perkembangan Zaman. Banjarmasin: Program Studi Magister Keguruan IPA PPs ULM.

Fuadah, F., Prastowo, S. H. B., \& Nuraini, L. (2019). Solusi Persamaan Schrodinger Atom Deuterium dengan Bilangan Kuantum n=4. FKIP e-PROCEEDING, 3(2), 142-147.

Masinta, A. D. \& Astutik, S. (2018). Identifikasi Keterampilanberpikir Kreatif dalam Menyelesaikan Soal Pemecahan Masalah Materi Elastisitas pada Siswa SMA. Seminar Nasional Pendidikan Fisika, 3(2).

Mulhayatiah, D. (2014). Penerapan Model Pembelajaran Berbasis Proyek untuk Meningkatkan Kemampuan Berpikir Kreatif Mahasiswa. EDUSAINS, 6(1), 17-22.

Nurmalasari, I. (2016). Pengaruh Model Project Based Learning terhadap Kemampuan Analisis pada Konsep Protista (Kuasi Eksperimen pada Siswa di SMA Negeri 87 Jakarta). Skripsi. Prodi Pendidikan Biologi FITK UIN Syarif Hidayatullah.

Rif'at, P.A.C., Wati, M., \& Suyidno, S. (2020). Developing Students' Responsibility and Scientific Creativity through Creative Responsibility Based Learning in Learning Physics. Berkala Ilmiah Pendidikan Fisika, 8(1), 12-22.

Sugiyono. (2012). Metode Penelitian Pendidikan (Pendekatan Kuantitatif, Kualitatif dan R\&D). Bandung; Alfabeta.

Suyidno., Dewantara, D., Nur, M., \& Yuanita, L. (2017). Maximize Student's Scientific Process Skill within Creatively Product Design: Creative Responsibility-Based Learning. Proceeding the 5th South East Asia Development Research (SEA-DR) International Conference. Banjarmasin, Indonesia, 3 Mei 2017.

Suyidno., Nur, M., Yuanita, L., Prahani, B. K., \& Jatmiko, B. (2018). Effectiveness of Creative Responsibility Based Teaching (CRBT) Model on Basic Physics Learning to Increase Student's Scientific Creativity and Responsibility. Journal of Baltic Science Education, 17(1), 136-151.

Suyidno., Susilowati, E., Arifuddin, M., Misbah., Sunarti, T., \& Koranto, D. (2019). Increasing Students' Responsibility and Scientific Creativity through Creative Responsibility Based Learning. Jurnal Penelitian Fisika dan Aplikasinya (JPFA). 2019; 9(2): 178-188

Suyidno., Susilowati, E., Arifuddin, M., Sunarti, T., Siswanto, J., \& Rohman, A. (2020). Barriers to Scientific Creativity of Physics Teacher in Practicing Creative Product Design. Journal of Physics: Conf. Series. 1941(2020)012048.

Triyono, T., Senam, S., Jumadi, J., \& Wilujeng, I. (2017). The Effects of Creative Problem Solvingbased Learning Towards Students' Creativities. Penelitian Inovasi Pembelajaran, 1(2), 229040.

Wahida, F. (2015). Pengaruh Model Pembelajaran Berbasis Proyek Terhadap Keterampilan Berpikir Kreatif dan Hasil Belajar Siswa Kelas X SMA Negeri 1 Parigi. Jurnal Sains Teknologi Tadulako, 4(3), 36-43.

Wulandari, F. E. (2016). Pengaruh Model Pembelajaran Berbasis Proyek untuk Melatihkan Keterampilan Proses Mahasiswa. PEDAGOGIA: Jurnal Pendidikan, 5(2), 247-254.

Yanti, L., Miriam, S., \& Suyidno. (2020). Mengembangkan Keterampilan Proses Sains Peserta Didik Melalui Creative Responsibility Based Learning. Jurnal Penelitian Pendidikan Sains, 9(2), 1790-1796.

Zainuddin., Suyidno., Dewantara, D., Mahtari, S., Nur, M., Yuanita, L., \& Sunarti, T. (2020). The Correlation of Scientific Knowledge-Science Process Skills and Scientific Creativity in Creative Responsibility Based Learning. International Journal of Instruction, 13(3), 307-316. 